成人鼠径ヘルニアに対する腹腔鏡下修復術の経験

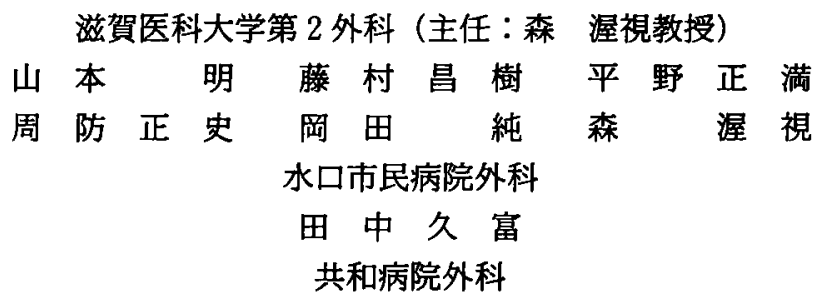

佐 藤 功添田世沢

1992年 7 月以来, 19例の成人㖩径ヘルニアに対し腹沿鏡下ヘルニア修復術を施行した。 また，同期間中11例の全身麻醉ハイリスク症例を中心に Nyhus 法に準じた preperitoneal posterior approachによる prosthetic repair を施行した. 一方，この期間を楜 る 1 年間に24例の従来法を施行した. われわれの施行している術式を紹介するとともに, これら三者の比較検討を行った. 術後経過時間はいまだ短期間であるが三者ともに再 発はみられていない.従来法に比し腹腔鏡下修復術は約 2 倍の手術時間を要していたが, 術後鼠径部の疼痛や腫脹は特殊な症例でみられたにすぎない，術後在院日数は三者間で 大差はみられなかった。これらの経験から本術式は高齢者, 大きなへルニア門を有する 例, 重労働従事者, 再発症例など従来法では困難例に属する症例にこそ適応があると思 われた. 本術式は tension free repair が主流となった鼠径へルニア手術の一翼を大きく 担うものと思われる.

索引用語：成人鴠径ヘルニア, ヘルニア修復術, 腹腔鏡下手術

はじめに

鼠径ヘルニア修復術は Bassini 以来多くの先達が 種々の術式を考案, 改良し現在に至っており, 最近て は tension free repair が推奖される気運にある゙。か 机れは, 1992年 7 月以来成人鼠径ヘルニアに対して, “いわす Bassini 法”ゃ “iliopubic tract repair”（以 下従来法)を排し, “腹腔鏡下ヘルニア修復術 (laparoscopic hernioplasty)” "2) (以下 LH) を取入れ，また全 身麻酔に対するハイリスク症例では preperitoneal posterior approachによる prosthesisをもちいた補

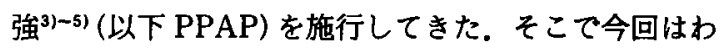
れわれの施行している術式の紹介と従来法との比較検 討を中心に報告する。

われわれの施行している LH の要点

われわれが自験例から得た LH 施行上の要点を中 心に術式を紹介する。

1993年11月17日受付 1994 年 2 月10日採用
1. 全身麻酔と気腹とトロッカーの择入

腰椎麻醉や硬膜外麻酔でも LH が可能とする報告 もみられるが,われわれは全身麻酷下に施行している. 気腹は胆摘術と同様に腈下部においた皮切開から気 腹針を用いて行い, 腹腔内压 $10 \mathrm{mmHg}$ で維持する.卜 ロッカーは腹腔鏡用を滕下部より，ヘルニアステイプ ル用および処置用を胼高で左右腹直筋外縁に刺入す る. 最初の腹腔鏡観察で右側へルニアのみであること が明らかなときは処置用トロッカーを左下腹部に置 き, 術者は患者の左側からのみ操作するようにした方 が操作が容易である.

\section{2. 腹腔側からの鼠径部の解剖}

腹腔鏡下胆摘術では開腹術での理解をそのまま腹肱 鏡観察に持ち込め,むしろ開腹より術野が良好なこと に驚かされる.しかし LH では, 従来法の臼径へルニ ア手術に習熟した術者においても腹腔側からの鼠径部 の解剖を直ちに理解するのは困難てある. ヘルニアの 有無, 部位は気腹による腹圧の上昇ゆえに容易である。 


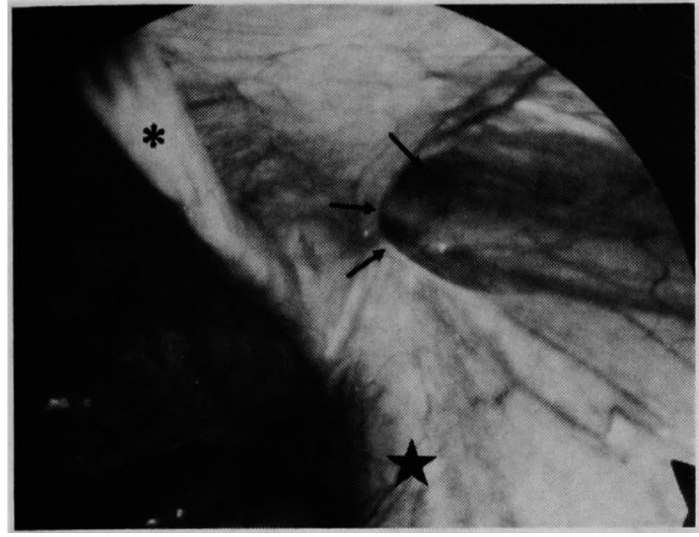

図 1 鼠径部の解剖：右鼠径部を示す，写真上は鼠径 部前腹壁, 左下方は骨盤腔, 右下方は腸腰筋。

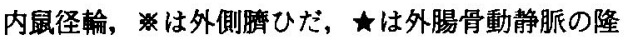
起を示す．腹腔側からは気腹の影響もあり，ヘルニ ア門の位置や大きさは非常にわかりやすい，本例は 外鼠径へルニアである。

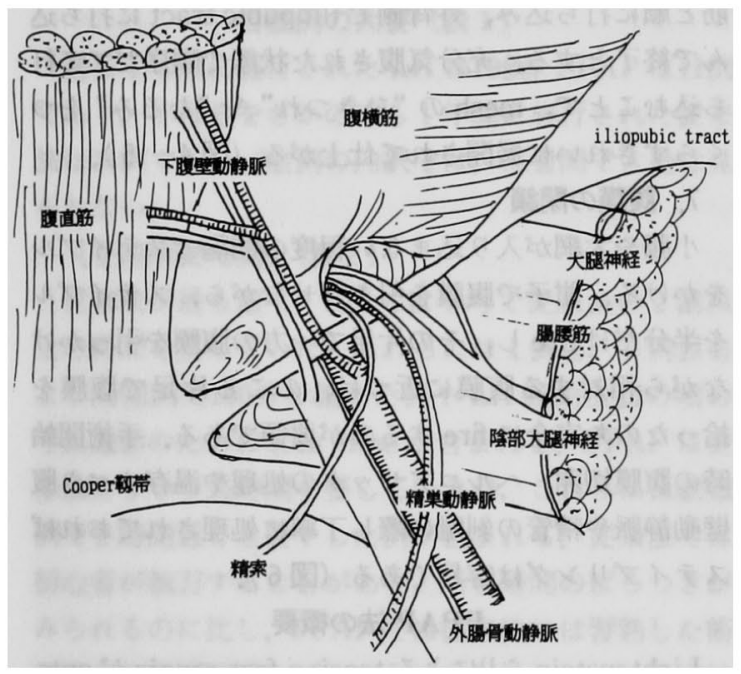

図 2 鼠径部の解剖：右鼠径部で腹膜の除去された状 態の模式図を示す.

腹膜前脂肪組織の少ない症例では鼠径部の解剖の全貌 を透見できる．腹膜が除去された鼠径部の解剖を示す (図 1, 2).

\section{3. 腹䑏の切開と剩離}

いかなる鼠径部へルニアであれ, prosthesis を安全 確実に固定するためには下腹壁動静脈, 精巣動静脈, 精管, 外腸骨動静脈のみならず, iliopubic tract, Cooper 靶帯, 腹横筋, 腹直筋, 腸腰筋など鼠径部を構成す

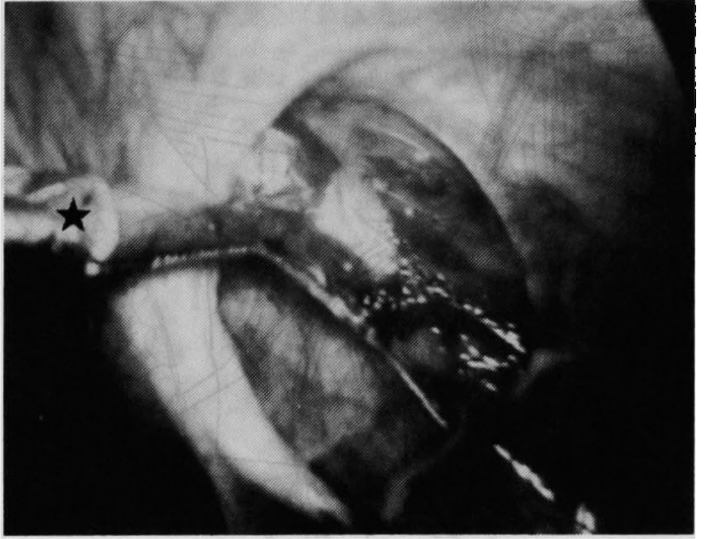

図 3 腹膜の切開と剩離：右外鼠径ヘルニア例. \は 剝離鉗子を示す.ヘルニア門の $1 \mathrm{~cm}$ 程腹側て腹膜に 切開をおく。

る一切の構造を明らかにすべきである。まずへルニア サックの処理を兼ねた腹膜切開をへルニア門の約 $1 \mathrm{~cm}$ 程腹側を中心に iliopubic tract に平行に $4 \sim 5 \mathrm{~cm}$ 置き 制離をはじめる．腹膜前脂肪組織の多い症例では破片 となった脂肪塊が煩わしく，われわれはガーゼを約4 $\mathrm{cm}$ 幅に切って大きなツッペルをつくり, 剥離, 脂肪除 去, 血液吸収に利用し重宝している（図3）。

\section{4. ヘルニアサックの処理}

腹空鏡下にへルニアサックの全摘出を試みることは 精管や精巣動静脈の損傷および術後鼠径管の腫脹をき たす可能性がある.そのため小さなサックでは先述の 腹膜切開, 剥離に際し引出し腹腔側へ脱転し, そのま ま腹膜の修復に利用する、大きなサックではへルニア 門より末梢側で離断し放置するか鼠径管外側に割を入 れるのみとするのが望ましいと思われる。残存した末 梢側のサックに浸出液の貯留のみられる頻度は決して 多くはない.

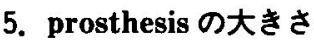

prosthesis として Prolene や Marlexを用いてい る. 本法のメリットである内, 外, 大䭆へルニアの同 時処理のためには内側は腹直筋外緑, 外側は腸腰筋, 上方は腹横筋筋膜，下方は Cooper 鞓帯にかかる大き さが必要であり, 平均的日本人の体格からは少なくと も約 $8 \times 6 \mathrm{~cm}$ 以上の大きさが必要と思われる。もちろ ん体格によりその大きさは異なり, 欧米文献では $12 \times$ $10 \mathrm{~cm}$ 程度の報告が多い6).われわれは開いた剩離釹子 を用いて採寸し,それに5〜10 $\mathrm{mm}$ 余裕をもたせた大き さとし，ほほ中央で下腹壁動静脈起始部と外腸骨動静 


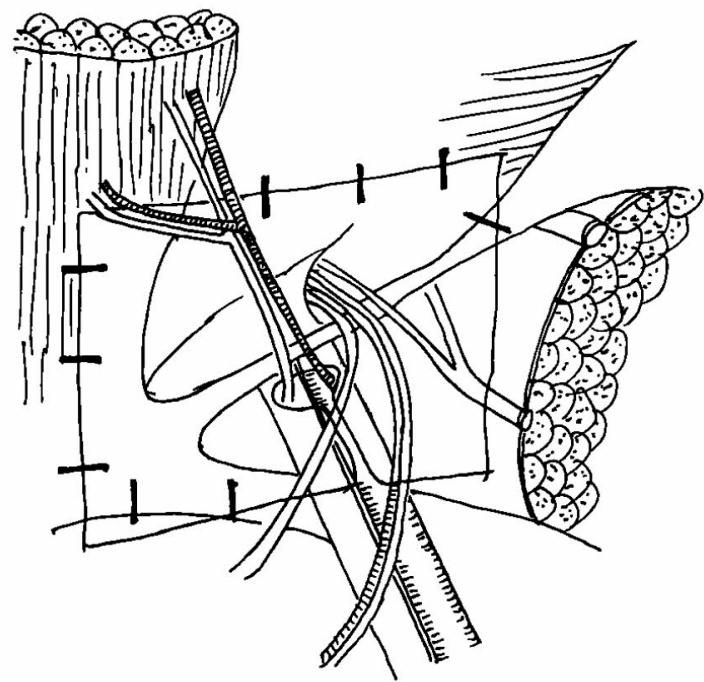

図 4 mesh の大きさと固定：図 2 で示した模式図に mesh を重ねたもの. 約 $6 \times 8 \mathrm{~cm}$ 大の mesh にスリッ トを入れ，下腹壁動静脈の襄面を通す．一はヘルニ アステイプルを示す. いわゆる Triangle of Doom や腸腰筋には打ち込まれていないことを示す。

脈を跨ぐ部で Triangle of Doom（精巣動静脈と精索 を二辺とし頂点を内鼠径輪として想定した三角形で, 中央を外腸骨動静脈が走行する）の外側辺（精巣動静 脈）に平行にスリットを入れる(図4).スリットを入 れることの是非はいまだ結論は出ていない。スリット を入れず，メッシュを下腹壁動静脈の裏面に通さずそ のまま動静脈をも被っている報告もある。

\section{6. prosthesis $の$ 固定}

ヘルニアステイプルによる固定は mesh の滑脱移動 を防止するためであり, 頑強, 密である必要はない. また神経，血管系を避けるのが当然であり，とりわけ 腸腰筋筋膜下を走行する陰部大朋神経や大羪神経への 打ち込みを防止するため腸腰筋への打ち込みは避ける

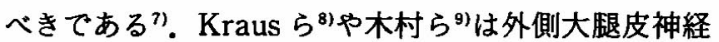
を挙げているが，同神経は大駸神経より更に外側を走 行し, 術野に現れない. 局所解剖の譟認があるものと 思われる．われわれは下腹壁動静脈の裏面を通し，か つスリットの基部を下腹壁動静脈の起始部にあわせる ことで mesh をスムーズに展開するための基点とす る.また mesh は腹腔鏡の光を反射し, mesh 越しに安 全性を確認するのは困難である，meshにスリットを 入れることで主要温存血管のメルクマールとなり誤つ て打ち込む事がない，またステイプルは右側へルニア

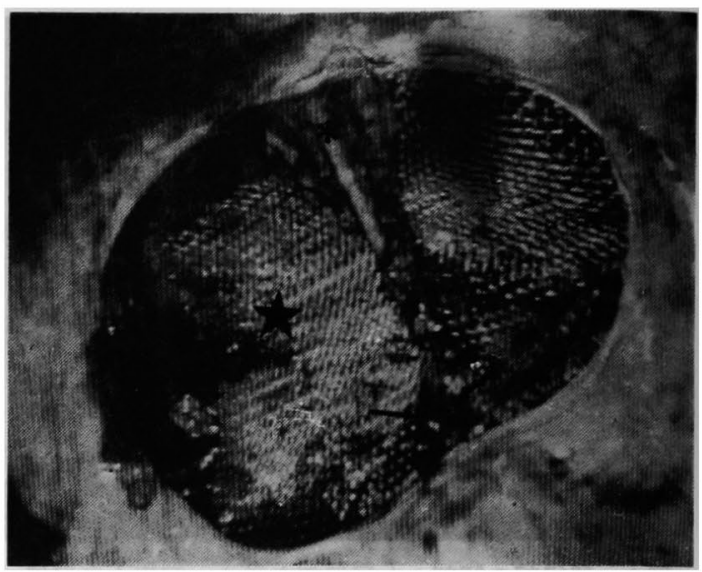

図 5 mesh の固定: 腹膜切開創から固定された mesh ( $\star$ )がみえる. ※は下腹壁動静脈を示し, mesh はその颢面にある。 $は$ mesh に入れられたスリッ トを示す。

では時計回りに, Cooper 靱帯から始め, 腹直筋, 腹横 筋と順に打ち込み，外背側で iliopubic tract に打ち込 んで終了とする. 充分気腹された状態で順序だてて打 ち込むことで, meshの“ひきつれ”ゃ“たるみ”をつ くらずきれいに展開されて仕上がる（図4，5）.

\section{7. 腹膜の閉鎖}

小腸や大網が入り込まない程度の間隔でステイプル をかける. 鉗子で腹膜を引き寄せながら，ステイプル を半分だけ fire し，その片足で一方の腹膜を引っかけ ながら相対する腹膜に近づけ，のこる片足で腹膜を 拾ったのち完全に fireするのが要領である．手術開始 時の腹膜切開, ヘルニアサックの処理や温存すべき腹 壁動静脈や精管の剥離に際し丁寧に処理されておれば ステイプリングは容易である（図6).

\section{PPAP 法の概要}

Lichtenstein $ら^{11} に よ る$ tension free repair が anterior approachにより剥離した内腹斜筋と鼠径勒带と の間に Marlex meshを扝き補強する onlay graft で あるのに対し, Nyhus ら゙やや柵瀬”は腹筋を皮用と同レ ベルで切離ののち腹膜外で鼠径部に到達し（preperitoneal posterior approach), ヘルニア門縫合閉鎖と Marlex meshによる補強を加えた術式を明らかにし た、われわれのPPAPはほほこれに準じて施行してい る. 本法の mesh による補強範囲は LH での prosth. esisによる被覆範囲に等しい.すなわち LH との差異 は, 腰椎麻酔で可能なこと, anterior approach より大 きな皮虙切開と筋層の切離を行うこと, mesh の固定 


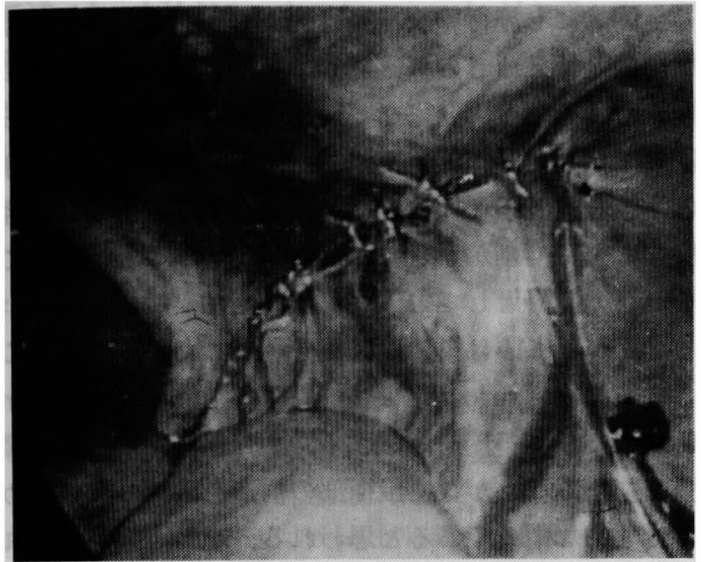

図 6 腹膜の閉鎖：ヘルニアステイプルで腹膜が閉鎖 されている．下方に回腸がみられる.

が金属クリップではなく縫合固定であること，そして 術野の展開が容易ではないことなどである.

\section{自験例の大要（表 1 )}

過去 1 年間に施行された LH は19例, PPAP は11例 であり，それらをさかのほる 1 年間に施行された従来 法は24例である，症例の内訳では，三者間で大差は見 られない.

[手術所要時間]（表 2)

従来法が最も短く, LH では平均で従来法の 2 倍以 上の時間を要していた．これらには 1 例目，2 例目お よび両側例で160分を越えた例や $\mathrm{LH}$ 開始当初の頃の 写真撮影のための loss time が含まれる.PPAP は従 来法よりやや長時間を要しているが，これらには嵌頓 例で 2 時間近くを費やした例が含まれる，従来法では 初心者が執刀することがあり，所要時間のばらつきが みられるのに比し，PPAP では従来法には習熟した術 者であり所要時間のばらつきは少ないものの, 従来法 に比して, 術野の展開が煩雑なことと末だ経験不足の ため従来法よりやや長時間を要していると思われる.

LH の開始初当は術野のオリエンテーションの理解が 困難なうえに，若干の出血でも術野の污染により更に 解剖の理解が困難になったことやへルニアサックの完 全掊除を試みたことなどから長時間を要したものと思 われる. 最近の両側へルニア症例で皮切から創閉鎖ま で90分で施行できるようになった。これは胆石症に比 しヘルニア症例の蓄積のテンポが遅いため, 従来の anterior approach とは全く異なる術野になじみきれ ないことや手技の確立が進まなかったことなどが挙げ
表 1 自験例の概要

\begin{tabular}{c|c|c|c}
\hline & 従来法 & PPAP & L.H. \\
\hline 例 数 & 24 & 11 & 19 \\
男 女 比 & $20: 4$ & $8: 3$ & $17: 2$ \\
年龄(歳) & $57.5(37-87)$ & $62.5(43-83)$ & $59.8(24-76)$ \\
部 位 & & & \\
内 & 0 & 1 & 3 \\
外 & 21 & 8 & 15 \\
大駺 & 1 & 2 & 1 \\
両側 & 2 & 0 & 3 \\
\hline
\end{tabular}

表 2 手術時間と術後在院日数

\begin{tabular}{l|c|c|c}
\hline & 従来法 & PPAP & L.H. \\
\hline 手術時間(分) & $52(39-105)$ & $78(51-114)$ & $120(90-170)$ \\
術後在院日数(日) & $5.8(2-19)$ & $6.2(3-10)$ & $5.3(2-9)$ \\
\hline
\end{tabular}

表 3 術後合併症

\begin{tabular}{|c|c|c|c|}
\hline & 従来法 & PPAP & L.H. \\
\hline 鼠径部痛 & $16 / 24(66 \%)$ & 0 & $3 / 19(17 \%)$ \\
\hline 創痛 & $?$ & $9 / 11(82 \%)$ & $2 / 19(11 \%)$ \\
\hline 腫脹 & $6 / 24(25 \%)$ & $1 / 11(9 \%)$ & $2 / 19(11 \%)$ \\
\hline 皮下気腫 & & & $3 / 19(17 \%)$ \\
\hline 右肩 痛 & & & $1 / 19(0.6 \%)$ \\
\hline 頭 痛 & $3 / 24(12.5 \%)$ & $4 / 11(36 \%)$ & \\
\hline
\end{tabular}

られる. 手技の習熟につれ60分以内で充分施行可能と 思われる。

【術後在院日数】（表 2 )

PPAP 例は高齢者を多く含むため, やや長い傾向に ある.いずれの術式を採用しても“退院可能ならば退 院する”という基本方針で臨んでいるため従来法でも 数日で退院した患者もいれば，LH でも 1 週間在院し た症例もある。術後在院日数は術後経過の良悪のみで 決定されているわけではなく，その当時の「ベッド事 情」や「患者の都合」など患者の病態以外の条件の介 入があり, 在院日数で術式の優劣を比較するのは困難 と思われる。

【術後合併症〕（表 3 )

未だ経過時間は短いが,三者ともに再発例をみない. 鼠径部痛は, 従来法ではいわする後壁補強に伴う率引 痛が66\%にみられ,他の二者での発生率と比較すると， 大きな隔たりがある. LHで3例にみられるが，LH 施 行第 1 ，第 2 例目で鼠径管内にロールにした mesh (plug)を挿入する方法を併用したため, 不快感を伴う 痛みを訴えた 2 例と, 瘾着のある大きなへルニアサッ 
クの全摘出に執着し鼠径管内容を徹底剥離したため術 後鼠径部腫脹をきたした症例である.PPAPでは皆無 であった．創痛について従来法では鼠径部の率引痛と 重なり評価は困難である. PPAPでは創が大きいこと や筋肉を切離, 縫合するため殆どの例でみられたが, せいぜい $3 ， 4$ 日の持続であり, 従来法でみられる鼠 径部率引痛に比し軽度でありまた自制可能な疼痛の質 と思われた，LHでみられた 2 例の創痛は臍部卜口 カール部の痛みで創閉鎖時の筋膜縫合によるものと思 われる。

鼠径部の腫脹は従来法では25\%でみられ, 臼径部率 引痛とともに患者の苦痛の大きなウエイトを占めてい る.一方大きなへルニアサックの全摘出を試みた PPAPの 1 例と LH の 2 例にも認められた。陰啐内ま で達するような大きなへルニアサックの全摘出を試み た場合は，いずれの術式を採用しても鼠径部から陰意 にかけての腫脹，血腫や疼痛などが生じ易いことが明 らかである.その他，LHでは陰毫部の皮下気腫，およ び右肩の痛みがみられた。また従来法や PPAPでは, 腰麻後の頭痛がみられた.

いまだ施行例数の少ない段階で LH と他術式の優 劣を結論することは困難である。しかし従来法に比し 術後早期の苦痛や愁訴が少なく, 日常生活への復帰が 早い(殆どの例で退院翌日より復㷌している)ことは 明らかである。

\section{考 察}

腹腔鏡下ヘルニア修復術は1990年米国の Ralph Ger の報告に始まる(0)．しかしその術式は内鼠径輪を金属 クリップで縫縮するものであった.その後 Corbitt ${ }^{11}$ や Schultz ら ${ }^{121}$ は mesh をロールにした “plug”を鼠径管 に挿入留置し，欠損部を充填する手技を開発したが， plug の移動, 鼠径部の高まりや硬結, 直接ヘルニアの 見逃しによる再発などが見られた。 そこでArregui ら²は腹膜を切開し prosthesisにより鼠径部を被覆す る方法を開発した. 現行の LH は基本的にこれに準じ ている.本邦では1991年12月頃より導入された まだ施行施設は限られている。その主たる原因はディ スポーザブル製品のトロッカーやステイプラーが高価 であり，かつ術式が保険適応となっていないことが挙 げられる。またへルニア手術はアッぺ，へモとならび 外科医を志す研修医が初期に執刀する容易な手術と考 えられていることから, 高価な器見と全身麻酔に対し 違和感がもたれていることも普及を妨げる一因となっ ている.
全国的にも施行施設，施行症例も少なく，いまた標 準術式といえるものも確立していない.また施行後の 経過時間も短く再発率など術後遠隔成績を云々できる 段階ではない．腹腔鏡下胆摘が通常の開腹胆摘と同様 の手技を腹腔鏡下に行うにすぎない故に手術侵堭の軽 度なことや術創が小さく, 疼痛が少ないこと, そして それらの結果としての入院日数の短縮が喧公されてい る.しかし LH は単に腹腔鏡を利用した手術であるこ とに留まらず, prosthesis を腹膜前に inlay し, tension freeにヘルニア門を閉鎖するため, 龱径部に無理な緊 張を強いることがなく鼠径部の構造を破壊しない極め て合理的な術式であると思われる. 現時点でわれわれ が考えるLHの利点を述べると，(1)まず meshを用い た補強であるため tension free repairであること。そ れ故率引痛を含む術後疼痛が少なく, 重労働従事者て も社会復帰までの日数は少なくて済む. (2)へルニア門 の大きさとは無関係に同一の術式で対応可能である. (3)して鼠径輪の締めすぎなどによる術後陰集浮腫, 圅丸萎縮などを皆無にできる. (4)さらに疫痕形成や加 齢などによる組織の脆弱化に基づく再発がない。（5)そ して, 内, 外, 大䀶ヘルニアを同時に処理でき,また 対側ヘルニアの有無の確認も容易であることなどが挙 げられる。これらのメリットから考えられる適応症例 は, 高齢者, 大きなへルニア門, 重労働従事者, 再発 ヘルニアなどであると思われる。すなわち従来法では 難度の高い症例こそが, 本法のより良い適応と思われ ろ. 一方欠点としては，(1)全身麻酔と気腹が必要であ る. (2)腹膜切開を行うため腸管凊着の可能性がある. (3)保険末収載でかつ処置具が高価である.などが考え られる。そのため心肺に異常を有し全身麻酔困難例て は禁忌であり，また下腹部手術既往例ては施行困難例 が含まれてくると思われる。

一方，われわれが全身麻酔に対するハイリスク症例 で試みている PPAP もほほ同様のメリットを有し再 発ヘルニアや後壁が脆弱もしくは欠損した大きなへル ニアに適応があるとされている(4). 本法は腹筋を切離 しているにも拘らず LHより良好な術野を展開する のは容易てはない，われわれは適応を拡大し, 再発例 に限らず初回例でも，LH の施行困難例では PPAPを 施行している.今後 LH と PPAP 両法の比較検討を継 続したいと考えている.

\section{むすび}

自験例の検討と $\mathrm{LH}$ 施行上の要点, および現段階て 考えられる利点と欠点そしてそれに基づく適応につい 
て述べた. LH は tension free repairが主流となった 鼠径ヘルニア手術のなかで術式選択に大きなウエイト を占めようとしている. 早期の保険適用と症例の畜積 による評価が待たれる。

\section{文献}

1) Lichtenstein IL, Shulman AG, Amid PK, et al: The tension-free hernioplasty. Am J Surg 157: 188-193, 1989

2) Arregui ME, Davis CJ, Yucel O, et al: Laparoscopic mesh repair of inguinal hernia using a preperitoneal approach : A preliminary report. Surg Laparosc Endosc 2: 53-58, 1992

3) Rignault DP: Properitoneal prosthetic inguinal hernioplasty through a Phannenstiel approach. Surg Gynecol Obstet 163: 465-468, 1986

4) Nyhus LM, Klein MS, Rogers FB, et al: Inguinal hernia. Curr Probl Surg $6: 407-450,1991$

5) 棚瀨信太郎 : Preperitoneal approach と mesh $k$ 上る補強について，消外 $15: 1483-1494,1992$

6) Filipi CJ, Fitzgibbons RJ, Salerno GM, et al: Laparoscopic herniorraphy. Surg Clin North
Am 72 : 1109-1124, 1992

7) Seid AS : Significance of groin nerve anatomy for laparoscopic hernia repair. Surg Endosc 7: 115, 1993

8) Kraus MA : Laparoscopic identification of preperitoneal nerve anatomy in the inguinal area. Surg Endosc 7: 114, 1993

9）木村泰三, 今泉 強, 吉田雅行他：腹些鏡下ヘルニ ア修復に伴う神経損傷を避けるための解剖学的検 討. 第 6 回内視鏡下手術研究会, 抄録集, 126, 1993

10) Ger $R$, Monroe $K$, Duvivier $R$, et al : Management of indirect inguinal hernias by laparoscopic closure of the neck of the sac. Am J Surg $159: 370-373,1990$

11) Schultz L, Graber J, Pietrafitta J, et al : Laser laparoscopic herniorraphy: A clinical trial preliminary results. J Laparoendosc Surg 1: 41 $-45,1990$

12) Corbitt JD: Laparoscopic herniorraphy. Surg Laparosc Endosc 1: 23-25, 1991

13）松本純夫：腹腔鏡下鼠径ヘルニア手術. 手術 47 : $645-650,1993$

\title{
EXPERIENCE OF LAPAROSCOPIC HERNIOPLASTY
}

\author{
Akira YAMAMOTO, Masaki FUJIMURA, Masamitsu HIRANO, Masashi SUO, \\ Jyun OKADA and Atsumi MORI \\ Second Department of Surgery, Shiga University of Medical Science \\ Hisatomi TANAKA \\ Department of Surgery, Minakuchi Shimin Hospital \\ Isao SATO and Seitaku SOEDA \\ Department of Surgery, Kyowa Hospital
}

Since July 1992, laparoscopic inguinal hernia repair was performed to 19 adult cases, and prosthetic repair by preperitoneal posterior approach (Nyhus-method), to 11 cases (high risk group for general anesthesia). And, conventional hernia repair was conducted to 24 cases from Jan' 1991 to June 1992. The postoperative results of three groups were comparatively examined.

No recurrence was observed on these three groups, though postoperative time for observation is still short in each method group. Laparoscopic repair demanded twice longer operation time than the conventional repair, but it was associated with groin pain and swelling in only a few particular cases. There was no significant difference in postoperative hospital stay among the three grousp. It seems that laparoscopic repair should be indicated for the aged, large hernia ring, hard laborer, and recurrent hernia which is intractable by conventional procedure.

Laparoscopic repair is reasonable operation which does not bring out postoperative groin pain and possibility of recurrence, because it dose not destroy any anatomical structure of inguinal region. Recently, tension free repair has become the principal procedure, and so, inguinal hernia repair will be mostly performed by laparoscopic repair. 